\title{
Menarche and Its Determinants in Adolescent Girls
}

\author{
Moushami Ghimire ${ }^{\mathrm{a}, \mathrm{d}}$, Achala Sharma ${ }^{\mathrm{b}}$, Madhusudhan Ghimire ${ }^{\mathrm{c}, \mathrm{d}}$
}

\begin{abstract}
:
Introduction: Biological, psychosocial, cognitive, emotional and social changes begin during puberty and continue throughout adolescence. The age at which a female reaches sexual maturity is critical in determining her future reproductive health and success. The aim of the study was to assess the average age of sexual feeling and menarche among the adolescent girls and its determinants. Methods: Three hundred fifty five respondents were selected through simple random sampling from three secondary schools (namely Sunrise Boarding School, Swaraswati Secondary School and Gyanjyoti Samudayak Bidhyalaya) in Palpa for the cross-sectional study. Structured interview schedule was used to collect information. Data was tabulated in Microsoft Excel spreadsheet and analyzed with SPSS-16. Results: Most of the girls (44.8\%) attained menarche at 12 years $(M=12.4, S D=1.11)$. Age at menarche was more likely before 13 years of age when the age of onset of sexual feeling was earlier than 12 years of age, in students than in domestic workers and if they are living with parents than in those not living with parents. Conclusion: The average age of menarche among the adolescent girls was 12.40 years and it could be influenced by age of sexual feeling, occupation and living status of girls.
\end{abstract}

Keywords: adolescent $\bullet$ menarche $\bullet$ puberty

\section{INTRODUCTION:}

The term adolescence means "to emerge" or "achieve identity" which is a relatively new concept, especially in developmental thinking. WHO defines adolescence both in terms of age (spanning the ages between 10 and 19 years) and in terms of a phase of life marked by special attributes which include rapid physical growth and development, physical, social and psychological maturity, but not all at the same time, sexual maturity and the onset of sexual activity, experimentation, development of

\footnotetext{
a - Lecturer

b - School of Social Science,

Jaipur National University, Jaipur, India

c - Assistant Professor

d - Department of Community Medicine,

Lumbini Medical College, Palpa, Nepal.

Corresponding Author:

Mrs. Moushami Ghimire

e-mail: bulbul2feb@yahoo.co.in

How to cite this article:

Ghimire M, Sharma A, Ghimire M. Menarche and its determinants in adolescent girls. Journal of Lumbini Medical College. 2014;2(1):10-3. doi: 10.22502/jlmc.v2i1.47.
}

adult mental processes and adult identity, transition from total socioeconomic dependence to relative independence. ${ }^{1}$ In girls, menarche starts during this period and girls feel shy to discuss the topic openly. A number of factors related to economic and social disadvantage put youth at risk of engaging in unprotected sex and becoming pregnant or acquiring an sexually transmitted disease (STD). ${ }^{2}$

Menarche is the first menstrual period generally occurring in early stages of adolescent girls. It is a part of the maturation process and an important milestone of puberty for most women in adolescent girls. Menarche age is an important indicator of reproductive health of a woman or a community. The first scientific record on age at menarche was 158 years ago. ${ }^{3}$ Strong evidence exists of a downward secular trend in the age at menarche; which appears to be associated with improved health and nutritional conditions. The mean age at menarche varies from population to population and is known to be a sensitive indicator of various characteristics of the population including nutritional status, geographical location, environmental conditions and socio-economic status. ${ }^{4-6}$ Over time, the age at 
menarche has been found to show a steady decline of about two to three months per decade in developed countries, $^{7}$ and about six months per decade in developing countries. ${ }^{8}$

Menstrual hygiene is a vital aspect of women's health. In many developing countries, a culture of silence surrounds the topic of menstruation and related issues; as a result many young girls lack appropriate and sufficient information regarding menstrual hygiene. This may result in incorrect and unhealthy behaviour during their menstrual period. There is paucity of literature regarding menarcheal age and the factors influencing it among adolescent girls of Nepal and this has been a less discussed topic. This study aims to find the variation of age at menarche in Nepalese adolescent girls and also evaluate the major factors affecting it through which reproductive health issues of women can be well addressed.

\section{METHODS:}

In this cross-sectional study, a total of 355 adolescent girls from three secondary schools (Sunrise Boarding School, Swaraswati Secondary school and Gyanjyoti Samudayak Bidhalaya) in Palpa district of Nepal were enrolled. Simple random sampling method was used for sample collection. A pretest procedure was applied in order to verify the reliability and validity of research tools. After getting informed consent from the respondents, data was collected through face-to-face structured interview schedule during the months of April to June 2014. All data was analyzed by SPSS 16 .

\section{RESULTS:}

Table 1 shows the socio-demographic profiles of adolescent girls $(N=355)$. Table 2 shows the age

Table 1: Socio-demographic profiles of adolescent girls $(N=355)$

\begin{tabular}{llcc}
\hline & Variables & $n$ & \% \\
\hline \multirow{2}{*}{ Education } & Primary & 10 & 2.8 \\
& Secondary & 345 & 97.2 \\
\multirow{2}{*}{ Family Type } & Nuclear & 249 & 70.1 \\
& Joint & 106 & 29.9 \\
Occupation & Student & 337 & 94.9 \\
& Domestic worker & 18 & 5.1 \\
Living with & No & 8 & 2.3 \\
parent & Yes & 347 & 97.7 \\
\hline
\end{tabular}

Table 2: Age distribution of adolescent girls, their sexual feeling and menarche $(N=355)$.

\begin{tabular}{|c|c|c|c|c|}
\hline \multicolumn{2}{|c|}{ Variables } & $n$ & $\%$ & $M, S D$ \\
\hline \multirow{3}{*}{ Age (years) } & $11-13$ & 149 & 42.00 & \multirow{3}{*}{$13.89,1.39$} \\
\hline & $14-16$ & 195 & 54.90 & \\
\hline & $\geq 17$ & 11 & 3.10 & \\
\hline \multirow{2}{*}{$\begin{array}{l}\text { Age at onset } \\
\text { of sexual } \\
\text { feeling }\end{array}$} & $<12$ yrs & 217 & 61.1 & \multirow[b]{2}{*}{$12.33,0.94$} \\
\hline & $\geq 12 \mathrm{yrs}$ & 138 & 38.9 & \\
\hline \multirow{5}{*}{$\begin{array}{l}\text { Age at } \\
\text { menarche } \\
\text { (years) }\end{array}$} & 11 & 33 & 9.3 & \multirow{5}{*}{$12.40,1.11$} \\
\hline & 12 & 159 & 44.8 & \\
\hline & 13 & 133 & 37.5 & \\
\hline & 14 & 28 & 7.5 & \\
\hline & 15 & 2 & 0.6 & \\
\hline
\end{tabular}

Table 3: Age at menarche and its relation with other factors $(\mathrm{N}=355)$

\begin{tabular}{|c|c|c|c|c|}
\hline \multirow[t]{2}{*}{ Variables } & & \multicolumn{2}{|c|}{$\begin{array}{l}\text { Age of } \\
\text { menarche } \\
\text { (in years) }\end{array}$} & \multirow[t]{2}{*}{ Relation } \\
\hline & & $<13$ & $\geq 13$ & \\
\hline \multirow{2}{*}{$\begin{array}{l}\text { Age at onset of } \\
\text { sexual feeling }\end{array}$} & $<12$ yrs & 164 & 53 & \multirow{2}{*}{$\begin{array}{l}X^{2}=1.012 \\
p<0.001\end{array}$} \\
\hline & $\geq 12$ yrs & 29 & 109 & \\
\hline \multirow[b]{2}{*}{ Occupation } & Student & 191 & 146 & \multirow{2}{*}{$\begin{array}{l}X^{2}=14.300 \\
p<0.001 \\
* * \text { expected } \\
\text { frequency }=8\end{array}$} \\
\hline & $\begin{array}{l}\text { Domestic } \\
\text { worker* }\end{array}$ & $2^{* *}$ & 16 & \\
\hline \multirow{2}{*}{$\begin{array}{l}\text { Living with } \\
\text { parent }\end{array}$} & Yes & 193 & 154 & \multirow{2}{*}{$\begin{array}{l}p=0.002 \\
\text { fisher exact }\end{array}$} \\
\hline & No & 0 & 8 & \\
\hline
\end{tabular}

${ }^{\star}$ Domestic worker $=$ Student working in other house.

distribution of adolescent girls, their sexual feeling and menarche. Table 3 shows age of menarche and its associated factors among the adolescent girls. It shows that the age at menarche was more likely before 13 years of age when the age of onset of sexual feeling was earlier than 12 years of age, in students than in domestic workers and if they are living with parents than in those not living with parents.

\section{DISCUSSION:}

Menarche and associated factors were assessed among the adolescent girls from three secondary schools in Palpa district of Nepal.

This study found that majority of the respondents experienced menarche at age of 12 years $(M=12.40, S D=1.11)$. Studies from different parts of India observed the variation of mean age of menarche as Maharashtra (12.99 years), ${ }^{9}$ Kolkata 
(12.3 years) ${ }^{10}$ Chandigarh (13.2 years) ${ }^{11}$ and Delhi (13.34 years), ${ }^{12}$ which is comparable to this study. Similar cross-sectional studies carried out in 1989 , 2000 and 2008 in a rural Gambian community of West Africa revealed a median menarcheal age of 16.06 (95\% CI; 15.67-16.45), 15.03 (95\% CI; 14.76-15.30) and 14.90 (95\% CI; 14.52-15.28) respectively. ${ }^{13}$

In Nepal, median age at menarche among the Tibetan speaking population living at 3250-3560 m in Upper Chumik was 16.2 years in $1983 .{ }^{14}$ Average age at menarche in different studies in different time in Nepal was found to be 12 years among the rural adolescent girls in 2007, ${ }^{15} 12.5$ years in Sunsari district in 2013, ${ }^{16} 12.94$ years in five government schools of Kailali district in 2014. ${ }^{17}$ Our study showed that the mean age at menarche among adolescent girls was $12.4(S D=1.11)$. A study on basic level school girls in Madina and Accra reported that the mean age at menarche was $12.74(\mathrm{SD}=1.15)$ years; a median age of 12.09 while most girls (90\%) had first menstruation before age 13 years which is comparable to that in the present study. ${ }^{18}$

Our study reported that menarcheal age was

\section{REFERENCES:}

1. World Health Organization (SEARO): Adolescence the Critical Phase, The challenges and the potential. New Delhi: World Health Organisation;1997.34p.

2. Kirby D, Emerging Answers: Research Findings on Programs to Reduce Teen Pregnancy (Summary). Washington, DC: National Campaign to Prevent Teen Pregnancy; 1997.p.31.

3. Ong KK, Ahmed ML, Dunger DB. Lvesson from large population studies on timing and tempo of puberty (secular trend and relation to body size): the European trend. Mol Cell Endocrinol. 2006; 254-5:8-12.

4. Chumlea WC, Schubert CM, Roche AF, Kulin HE, Lee PA, Himes JH et al. Age at menarche and racial comparisons in US girls. Pediatrics. 2003;111(1):110-13.

5. Swenson I, Havens B. Menarche and menstruation: a review of the literature. J Community Health Nurs. 1987;4(4):199-210.

6. Thomas F, Renard F, Benefice E, de Meeüs T, Guegan JF. International variability of ages at menarche and menopause: patterns and main determinants. Hum Biol.2001;73(2):271-90.

7. Wyshak G, Frisch RE. Evidence for a secular trend in age strongly associated $(p<0.001)$ with age at onset of sexual feeling of the girls, occupation and living status (living with parents or not). The downward trend in age at menarche to an average of 12-13 years in most developing countries has been well established as surveys show that urban, educated, middle-class girls in many countries are now starting their periods on average at 12.5 years or earlier, the same age as (or even younger than) their European and North American counterparts. ${ }^{19-23}$ There is overwhelming evidence of the declining age at which menarche occurs. ${ }^{24-26}$ The role of enhanced living situation, measured as improved access to health care, optimal nourishment and appreciating socio-economic status on the onset of menarche has been reported in both developed and developing countries. ${ }^{4-6}$

\section{CONCLUSION:}

This cross-sectional study concluded that the age at menarche was more likely before 13 years of age when the age of onset of sexual feeling was earlier than 12 years of age, in students than in domestic workers and if they are living with parents than in those not living with parents. of menarche. N Engl J Med. 1982; 306:1033-5.

8. Bagga A, Kulkarni S. Age at menarche and secular trend in Maharashtrian (Indian) girls. Acta Biologica Szeged. 2000;44(1-4):53-7.

9. Deo DS, Gattarji CH. Age at Menarche and Associated Factors. Indian Journal of Pediatrics. 2004;71(6):565-6.

10. Banerjee I, Chakraborty S, Bhattacharya NG, Bandopadhyay S, Saiyed HN, Mukherjee D. A cohort study of correlation between body mass index and age at menarche in healthy Bengali girls. Journal of the Indian Medical Association. 2007;105(2):75-8.

11. Sharma K, Talwar I, Sharma N. Age at menarche in relation to adult body size and physique. Ann Hum Biol. 1988 Nov-Dec;15(6):431-4.

12. Acharya A, Reddaiah P, Baridalynel. Nutritional Status and Menarche in Adolescent Girls in Urban Resettlement Colony of South Delhi. American J of Epidemiology. 1990;132(5):953-61.

13. Prentice S, Fulford AJ, Jarjou LMA, Prentice A. Evidence for a downward secular trend in age of menarche in a rural Gambian population. Ann Hum Biol. 2010 SepOct;37(5):717-21. 
Ghimire M. et al. Menarche and Its Determinants in Adolescent Girls.

14. Beall CM. Ages at menopause and menarche in a high-altitude Himalayan population. Ann Hum Biol. 1983;10(4):365-70.

15. Adhikari P, Kadel B, Dhungel Sl, Mandal A. Knowledge and practice regarding menstrual hygiene in rural adolescent girls of Nepal. Kathmandu Univ Med J. 2007;5(3):382-6.

16. Sapkota D, Sharma D, Budhathoki SS, Khanal VK, Pokharel HP. Knowledge and practices regarding menstruation among school going adolescents of rural Nepal. Journal of Kathmandu Medical College. 2013;(3):122-8.

17. Hamal M, KC Susma. Hygiene, Health Problems and Socio-Cultural Practices: What School Girls Do During Menstruation? IJHSR. 2014;4(4): 28-33.

18. Aryeetey R, Ashinyo A, Adjuik M. Age of Menarche among basic level school girls in Medina, Accra. Afr J Reprod Health. 2011;15(3):113-21.

19. Morabia A, Costanza MC. International variability in ages at menarche, first livebirth and menopause. World Health Organisation Collaborative Study of Neoplasia and Steroid Contraceptives. Am J Epidemiol. 1998 Dec;148(12):1195205.

20. Parent AS, Teilmann G, Juul A, Skakkebaek NE, Toppari J, Bourguignon JP. The timing of normal puberty and the age limits of sexual precocity: variations around the world, secular trends, and changes after migration. Endocr Rev. 2003 Oct;24(5):668-93.

21. Patton GC, Viner R. Pubertal transitions in health. Lancet. 2007 Mar;369(9567):1130-9.

22. Lloyd CB (ed.) (Panel on Transitions to Adulthood in Developing Countries; Committee on Population; Board on Children; Youth and Families; Division of Behavioral and Social Sciences and Education; Institute of Medicine; National Research Council). Growing up Global: The Changing Transitions to Adulthood in Developing Countries. Washington DC: The National Academy Press; Washington DC;2005. 16p.

23. Adali T, Koç I. Menarcheal age in Turkey: Secular trend and socio-demographic correlates. Ann Hum Biol. 2011;38(3):345-53.

24. Kaplowitz P: Pubertal development in girls: secular trends. Curr Opin Obstet Gynecol. 2006; 18(5):487-91.

25. Herman-Giddens ME, The Decline in the Age of Menarche in the United States: Should We Be Concerned? J Adolesc Health. 2007 Mar;40(3):201-3.

26. Abioye-kuteyi EA, Ojofeitimi EO, Aina OI, Kio F, Aluko $\mathrm{Y}$, Mosuro O. The Influence of Socioeconomic and Nutritional Status on Menarche in Nigerian School Girls. Nutrition and Health. 1997 Jan;11(3):185-95. 